\title{
WINERY WASTE MANAGEMENT IN SERBIA: VRANAC GRAPE MARC AS SOURCE OF ANTIOXIDANTS
}

\section{UPRAVLJANJE OTPADOM VINARIJA U SRBIJI: KOMINA VRANCA KAO IZVOR ANTIOKSIDANATA}

\author{
Vladimir Radovanović \\ University of Niš, Faculty of Science and Mathemathics, Niš, Serbia

\section{Snežana Đekić} \\ University of Niš, Faculty of Economics, Trg kralja Aleksandra 11, 18000 Niš, Serbia

\section{Blaga Radovanović} \\ University of Niš, Faculty of Science and Mathemathics, Niš, Serbia
}

\section{(C) MESTE NGO}

JEL category: Q5, Q53, Q56

\begin{abstract}
During winemaking of grape, large quantities of waste are produced. For example, by processing 100 kilograms of grape-vine approximately 20 - 25 kilograms of grape marc is produced. The placing of the enormous amount of waste grape (around 5 - 9 million tons per year) generated in all over the world is an increasing environmental problem. In recent years, the growing concern about the environment has led authorities to look for economically viable solutions for recycling and/or valorizing grape waste. Serbia is one of the major producers and consumers of grapes and wine in the Western Balkans, with a grape and wine production 330,070 tonnes and 1,700,000 hl of which remains about 7,000 tons of secondary products. Significant amounts of polyphenols found in grape, wine and grape by-products and a great interest in their exploitation. In this work, the content of polyphenols and antioxidant activity Vranac Vitis vinifera L. grape marc after obtaining red wine were investigated. Our results of analysis of grape waste show significant content of polyphenols reflecting their exellant antioxidant activity. It was concludes that the grape marc constitutes a very cheap source for the extraction of phenolic antioxidants, which can be used in food and pharmaceutical industries, thus providing an important economic advantage.
\end{abstract}

Corresponding author:

Blaga Radovanović

blaga_radovanovic@yahoo.co.uk
Keywords: Vranac grape marc, polyphenols, antioxidant activity, economic advantage 


\section{Apstrakt}

Pri proizvodnji vina ostaju velike količine otpada od grožđa. Na primer, preradom 100 kilograma grožđa ostaje oko 20 - 25 kilograma grožđane komine. Odlaganje ogromne količine otpada grožđa (u svetu se generiše oko 5 - 9 miliona tona godišnje) je narastajući ekološki problem. U poslednjih nekoliko godina, rastuća zabrinutost za životnu sredinu navela je vlasti da traže ekonomski održiva rešenja za reciklažu $i$ / ili iskorišćavanje otpada grožđa. Srbija je jedan od glavnih proizvođača i potrošača grožđa i vina na Zapadnom Balkanu. Uz proizvodnju 330.070 tona grožđai 1.700.000 hektolitara vina, ostaje oko 7.000 tona sekundarnih proizvoda. U grožđu, vinu i sporednih proizvodima grožđa nalaze se značajne količine polifenola i izazicaju veliko interesovanje za njihovu eksploataciju. $U$ ovom radu su ispitivani sadržaj polifenola $i$ antioksidativna dejstva Vranac Vitis vinifera L. grožđane komine ostale posle dobijanja crvenog vina. Naši rezultati analize grožđanog otpada pokazuju značajan sadržaj polifenola koji odražavaju njihovo izvanredno antioksidativno delovanje. Zaključeno je da grožđe predstavlja veoma jeftin izvor za ekstrakciju fenolnih antioksidanata, koji se može koristiti u hrani i farmaceutskoj industriji, čime se obezbeđuje važna ekonomska prednost.

Ključne reči: Vranac, komina, grožđe, polifenoli, antioksidativna aktivnost, ekonomska prednost

\section{INTRODUCTION}

According to the Food and Agriculture Organization (FAO), in 2012 world vineyards reached a total area surface (which includes areas not yet in production or harvested) of 7528000 ha, global grape production of 69200000 tones and world wine production (excluding juice and musts) of $252000 \mathrm{hl}$ (International Organization of Vine and Wine - OIV, 2012). Approximately $71 \%$ of world grape production is used for wine, $27 \%$ as fresh fruit, and $2 \%$ as dried fruit.

Serbia is one of the major producers and consumers of grapes and wine in the Western Balkans, with a grape production was 330070 tonnes and wine production was $1,700,000 \mathrm{hl}$ of which remains about 7,000 tons of secondary products, which is only used for the production of alcohol, and most of ending up in landfills as organic waste (Statistical Serbian Office, 2012).

However wine making leads to the generation of large quantities of waste (around 5-9 million tons per year, worldwide), which considerably increase the chemical oxygen demand (COD) and the biochemical oxygen demand (BOD) due to a high pollution load with detrimental effects on the flora and fauna of discharged zones (Greben and Oelofse, 2009; Oreopoulou et al., 2007). The composition of grape waste varies considerably, depending on grape variety, vintage and technology of winemaking. Thus, the waste generation of the winery industry was estimated for a wine production of 159.3 Miohl in, approximately $1138 \times 10^{3}$ tons/year of grape stalk, $3186 \times 10^{3}$ tons/year of grape marc, $1365 \times 10^{3}$ tons/year of wine lees and $95 \times 10^{6} \mathrm{~m} 3$ of winery wastewater (OIV, 2010).

The treatment and disposal of winery waste must is a serious environmental problem and treatment due to their seasonal character (during September - November) and some characteristics which difficult their management. The cost of waste disposal and the penalties imposed on companies have therefore increased significantly, often reaching 30,000 - 40,000 Euros in EU. Extensive research has demonstrated that many biodegradable organic wastes can be composted in a convenient and economical way. Composting of organic matter is a simple and efficient manner of transforming agro-industrial wastes into the products suitable for use as soil conditioners animal feed, fertilizers, vermicomposts, preservative etc (Garrido et al., 2011; Paradelo et al., 2011, 2012; Zheng et al., 2912).

In recent years, the growing concern about the environment has led authorities to look for economically viable solutions for recycling and/or valorizing grape waste (Ping et al., 2011; Prozil et al., 2012; Spigno and De Faveri, 2007).

The studies in animals, as well as some human studies, have shown that grape polyphenols possess a broad spectrum of biological, pharmacological and chemo-protective properties against free radicals and oxidative stress (Adamez et al., 2012; Andjelković et al, 2013; Arvanitoyannis et al., 2006; Baydar et al., 2004; 
Jayaprakasha et al., 2003; Katalinić et al., 2010; Nedeljković et al., 2013;. Radovanović et al., 2012).

Researchers at Oregon State University (OSU) have discovered how to turn the pulp from crushed wine grapes into a natural food preservative, biodegradable packaging materials and a nutritional enhancement for baked goods. "We now know pomace can be a sustainable source of material for a wide range of goods," said researcher Yanyun Zhao, a professor and valueadded food products specialist with the OSU Extension Service. "We foresee wineries selling their pomace rather than paying others to dispose of it. One industry's trash can become another industry's treasure." The researchers have dried and ground it to create edible and non-edible products. For example, they extracted dietary fiber from grape pomace and turned it into powders that can be added to foods.

Because significant amounts of antioxidants phenolic compounds in grape pomace, which are gluten-free and control microbial growth, the researchers also added the pomace powdery fiber to yogurts, salad dressings, muffins and brownies, replaced up to 15 percent of the flour in the recipes with it and thus increased the fiber and antioxidants in the baked goods. The research continues as scientists are also adding pomace to yeast breads (Tseng and Zhao, 2013).

Researchers found that the methods for making products from grape marc (pomace) vary depending on if the pulp is from red or white grapes. That's because winemaking processes differ for each varietal and they produce pulp with different levels of sugar, nitrogen, phenolics and other compounds. In this work is to evaluate the content of polyphenols and antioxidant activity of autochthonous grape variety Vranac (Vitis vinifera L.) waste (grape seeds, skins and stems) and grape marc (pomace) after obtaining a red wine Vranac, which is most common in Serbia.

\section{MATERIAL AND METHOD}

\subsection{Chemicals}

Gallic acid, caffeic acid, quercetin, malvidin-3glucoside chloride and 2,2'-diphenyl-1picrylhydrazyl (DPPH) free radical were supplied from Sigma Chemical Co. (St. Louis, MO). Acetone, ethanol, methanol, acetic acid, and hydrochloric acid were obtained from Merck (Darmstadt, Germany). The reagents used were of analytical quality.

\subsection{Samples}

The grape Vranac (Vitis vinifera L.) was collected from southern Serbia vineyard region in midOctober, after harvest. The grape marc (pomace) and stems was taken from local winery. Samples of grape stems and marc were washed and dried at $60{ }^{\circ} \mathrm{C}$. One part of grape marc was used for separating grape seeds and skins.

\subsection{Extraction Procedure}

The samples of dry grape waste were extracted with solvent system 30/42/27.5/0.5 of methanol/acetone/water/acetic acid by stirring continuously at room temperature in dark for 30 min and then centrifuged at room temperature (Tehnica LC-320, Zelezniki, Slovenia) at $4000 \mathrm{rpm}$ for 10 min the supernatants from three extraction procedures. Extracts were filtered through a 0.45 $\mu \mathrm{m}$ syringe filter before analysis.

\subsection{Determination of polyphenols}

Polyphenols in selected extract samples were determined spectrophotometrically (Agilent 8453 UV/VIS spectrophotometer, Santa Clara, CA, USA), with modificated method (Mazza et al., 1999). The absorbance at $280 \mathrm{~nm}$ was used to determine total phenolic content and results were expressed as grams gallic acid equivalents.

\subsection{Determination of antioxidant activity}

Antioxidant activity of test grape samples was determined by using DPPH free radical scavenging assay (Radovanović et al., 2012). This antioxidant method is based on the measurement of DPPH colour loss due to the changes in absorbance at $517 \mathrm{~nm}$, caused by the reaction of DPPH - with the test sample. The antioxidant activity (AA) of each sample was calculated from the decrease in absorbance according to the following relationship:

$\mathrm{AA}(\%)=\left[1-\left(A_{\text {sample }}-A_{\text {blank }}\right) / A_{\text {control }}\right] \times 100$ 
where:

$A_{\text {control }}$ is the absorbance of control,

Ablank is the absorbance of sample and

$A_{\text {sample }}$ is the absorbance of the sample with the same concentration of DPPH free radical as in control.

The antioxidant activities of investigated extracts were expressed as median efficient concentrations $\left(\mathrm{EC}_{50}\right)$.

\subsection{Statistical analysis}

Three analytical replicates were carried out on each grape sample. Measurements were averaged and results are given as mean \pm standard deviation (SD).

\section{RESULTS AND DISCUSION}

The phenolic composition in grape varies widely and is usually determined by several factors, such as, the variety of grape and conditions under which they was grown (soil, geographical location, light exposure, temperature, sun exposure of the clusters, location of growth, ripening time) and other factors (Lachman et al., 2009).

Researchers found that the methods for wine making products from grape pomace vary depending on if the pulp is from red or white grapes. That's because winemaking processes differ for each varietal and they produce pulp with different levels of sugar, nitrogen, phenolics and other compounds.

Table 1. Chemical composition of grape marc (wt\%, DW)

\begin{tabular}{|l|l|}
\hline Component & Red grape marc \\
\hline Cellulose & 14.5 \\
\hline Hemicellulose & 10.3 \\
\hline Pectin & 5.4 \\
\hline Lignin & 17.2 \\
\hline Protein & 14.5 \\
\hline Sugars & 2.7 \\
\hline Total C & 48.2 \\
\hline
\end{tabular}

Source: (Zheng et al., 2012)

The chemical composition of grape marc is a potential source of different organic compounds. The grape marc generated as solid residue after wine making process, has the chemical composition shown in the table 1 .
Polyphenols represent the third most abundant constituents in grapes after carbohydrates and fruit acids (Mazza et al., 1999).

The plants produce phenols as a response to the negative impacts from the environment as well as UV radiation, various pathogens, fungi etcAlso, the amount and types of phenol compounds present in a particular grape waste extracts can vary and is greatly influenced by the extraction in the winemaking process (Spigno and De Faveri, 2007).

Also, the amount and types of phenol compounds present in a particular grape marc extracts can vary and is greatly influenced by the extraction in the winemaking process (Spigno and De Faveri, 2007).

The utilization of grape skins, stalks and seeds have an important environmental impact in waste reduction and permit the production of added value products in food industry.

In the investigated samples of Vranac grape showed that berry clusters took part in the structure of the cluster with an average of $95.55 \%$ and grape stems with $4.35 \%$.

The analysis showed that the berry in a cluster share the grape seeds on average was $7.36 \%$, grape skins $32.74 \%$ and grape pulp $60.25 \%$, which is in agreement with literature data (Baydar et al., 2004; Katalinić et al., 2010; Mattivi et al., 2009).

The results of content of total polyphenols and antioxidant activity of grape waste extracts, obtained from Vranac grape stalks, seeds, skins from grape marc and grape marc (pomace) after winemaking, and their antioxidant activity are shown in Table 2. The obtained results showed significant polyphenolic contents in all tested samples, ranged from 51.73 to $113.25 \mathrm{~g} / \mathrm{kg} \mathrm{DW}$, in agreement with literature data (Anastasiadi et al., 2009; Dani et al., 2010).

Lower $\mathrm{EC}_{50}$ values correspond to higher antioxidant activity of extracts (Table 2). All extracts showed antioxidant activity, ranged from 0.37 to $2.02 \mathrm{~g} / \mathrm{L}$, corresponding with total polyphenol contents in them. The highest antioxidant activity showed extracts of grape seed, followed by vine leaves, grape stalks, marc and skins. 


\section{Table 2. Phenolic composition ( $/ \mathrm{kg} D W$ ) and antioxidant activity, $E C_{50}(g / L D W)$ of Vranac grape marc extracts}

\begin{tabular}{|l|c|l|}
\hline Extract & Polyphenols & $\begin{array}{l}\text { Antioxidant } \\
\text { activity, } \mathbf{E C}_{50}\end{array}$ \\
\hline Grape stalk & $73.99 \pm 0.28$ & $0.73 \pm 0.06$ \\
\hline Grape seed & $113.25 \pm 0.89$ & $0.37 \pm 0.01$ \\
\hline Grape skin & $51.73 \pm 0.19$ & $2.02 \pm 0.07$ \\
\hline Grape marc & $67.40 \pm 0.38$ & $1.16 \pm 0.03$ \\
\hline
\end{tabular}

Between antioxidant activity and total polyphenol content was found exellant correlation $(R=0.8883$ $\pm 0.3407, \mathrm{P}<0.05)$ (Figure 1).

Strong antioxidant activity of grape seed extracts, corresponding to their high polyphenol content, suggests that the polyphenols at least partially are responsible for the biological properties of these extracts.

The grape seeds stand for the most popular byproducts of grape wastes in the most representative market of the world.

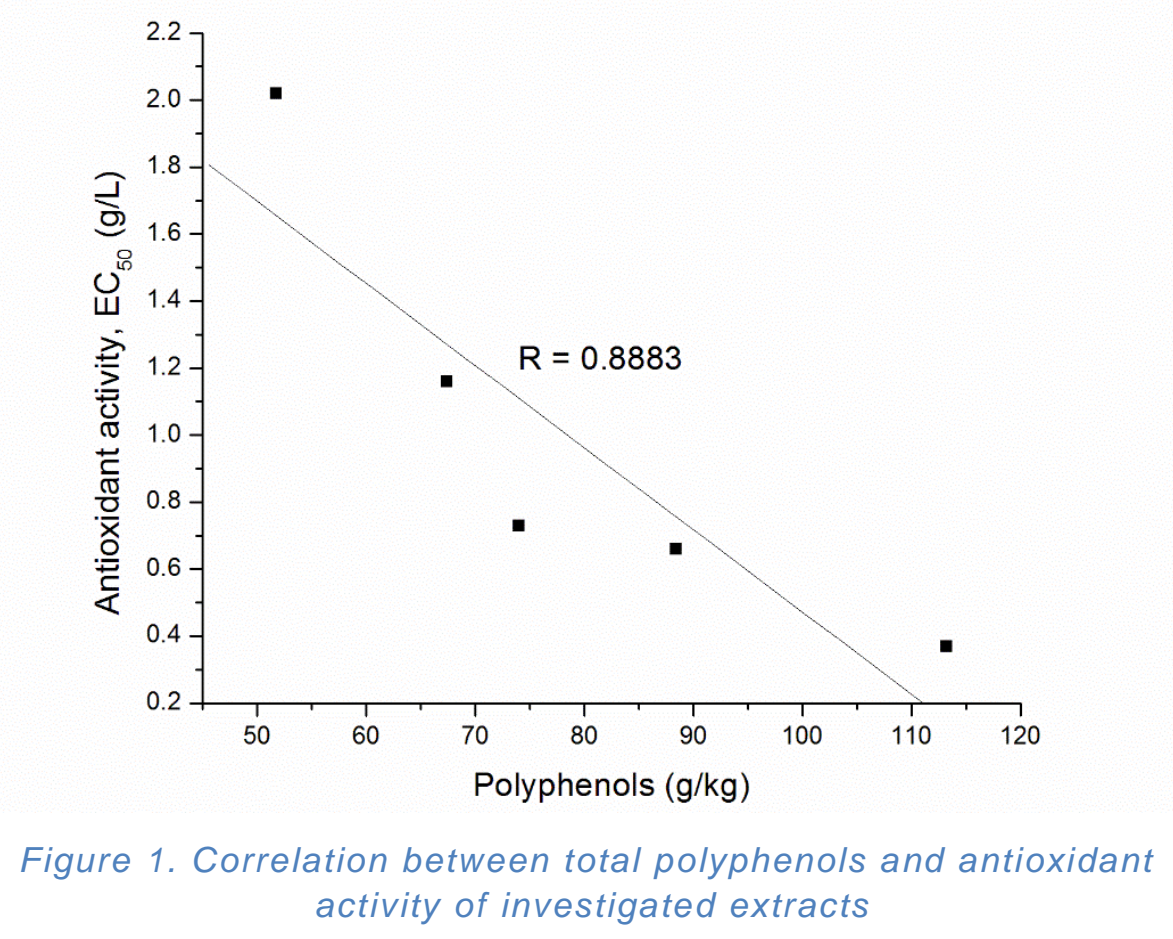

These grape residues could be an alternative source for obtaining natural antioxidants and are considered completely safe in comparison with synthetic antioxidants.

\section{CONCLUSIONS}

The wine industry produces a large quantity of grape waste and the problem of handling winery waste has been part of winery management for years. Based on results of this research we can conclude that the extracts of Vranac grape waste were rich of polyphenols and have significant antioxidant activity, which is in correlation with their total polyphenolic content. For this reason, extraction of polyphenols from grape waste can lead to an increase in economic potentials in food and pharmaceutical industries with undesirable effects on the enzymes of human organs and decrease of waste material generated.

\section{WORKS CITED}

Anastasiadi, M., Chorianopoulos, G., Nychas, E. \& Haroutounian, A. (2009). Antilisterial activities of polyphenol-rich extracts of grapes and vinification byproducts. Journal of Agriculture and Food Chemistry, 57, 457-463. 
Andjelković, M., Radovanović, B., Radovanović, A. \& Andjelković. A. (2013) Changes in Polyphenolic Content and Antioxidant Activity of Grapes cv Vranac During Ripening. South African Journal of Enology and Viticulture. 34 (2), 147-155.

Arvanitoyannis, I, Ladas, D. \& Mavromatis, A. (2006). Potential uses and applications of treated wine waste: a review. International Journal of Food Science and Technology, 41, 475-487.

Baydar, G., Ozkan, G., Sagdic, O. (2004). Total phenolic contents and antibacterial activities of grape (Vitis vinifera L.) extracts. Food Control, 15, 335-339.

Di Stefano, R. (1996). Metodi chimici nella caratterizzione varietale, Rivista di Viticoltura e di Enologia, $1,51-56$.

Garrido, D., Auqui, M., Marti, N. \& Linares, B. (2011). Effect of two diferrent red grape pomace extracts obtained under different extraction systems on meat quality of pork burgers. Food Science and Technology, 44, 2238-2243.

Greben, A. \& Oelofse, H. (2009). Unlocking the resource potential of organic waste a South African perspective, Waste Management \& Research, 27, 676-684.

Jayaprakasha, K., Selvi, T. \& Sakariah, K. (2003). Antibacterial and Antioxidant Activities of Grape (Vitis vinifera) Seed Extracts. Food Research International, 36, 117-122.

Katalinić, V., Mozina, S., Skroza, D., Generalić, I., Abramovic, H., Milos, M., Ljubenkov, I., Piskernik, S., Pezo, I., Terpinc, P. \& Boban, M. (2010). Polyphenolic profile, antioxidant properties and antimicrobial activity of grape skin extracts of 14 Vitis vinifera varieties grown in Dalmatia (Croatia). Food Chemistry, 119, 715-723.

Lachman, J., Šulc, M., Faitova, K. \& Pivec, V. (2009) Major factors influencing antioxidant contents and antioxidant activity in grapes and wines. International Journal of Wine Research, 1, 101-121.

Mattivi F, Vrovsek U, Masuero D and Trainotti D (2009) Differences in the amount and structure of extractable skin and seed tannins amongst red grape varieties. Australian Journal of Grape and Wine Research 15: 27-35.

Mazza, G., Fukumoto, L., Delaquis, P., Girard, B. \& Ewert, B. (1999). Anthocyanins, Phenolics, and Color of Cabernet Franc, Merlot, and Pinot Noir Wines from British Columbia. Journal of Agricultural and Food Chemistry, 47, 4009-4017.

Nedeljković, N., Sakač, M., Mandić, A., Mišan, A., Jovanov, P., Jambrec, D., Banjac, V., Šarić, B., \& Pestorić, M. (2013). Antioksidativna aktivnost bezglutenskog keksa obogaćenog heljdinim brašnom. Journal on Processing and Energy in Agriculture, 17(2), 93-96.

Oreopoulou, V. \& Tzia, C. (2007). In utilization of by-products and treatment of waste in the food, pp 209-232 (Russ. Eds.), Springer, USA.

Paradelo, R., Moldes, B. \& Barral, T. (2011.) Carbon and nitrogen mineralization in a vineyard soil amended with grape marc vermicompost. Waste Management \& Research, 29, 1177-1184.

Paradelo, R., Moldes, B., Gonzalez, D. \& Barral, T. (2012). Plants tests for determining the suitability of grape marc composts as components of plant growth media. Waste Management \& Research, 30, 1059-1065.

Ping, L., Pizzi, A., Guo, D. \& Brosse, N. (2011). Condensed tannins extraction from grape pomace: characterization and utilization as wood adhesives for wood particleboard. Industrial Crops and Products, 34, 907-914.

Prozil, O., Evtuguin, V. \& Lopes, P., (2012). Chemical cvomposition of grape stalks of Vitis vinifera L. from red grape pomaces, Industrial Crops and Products, 35, 178-184.

Radovanović, A., Jovancicević, B., Radovanović, B., Mihajilov-Krstev, T. \& Zvezdanović, J. (2012). Antioxidant and antimicrobial potentials of Serbian red wines produced from international Vitis vinifera grape varieties. Journal of Science and Food Agriculture, 92, 2154-2161.

Spigno, G. \& De Faveri, M. (2007). Antioxidants from grape stalks and marc: Influence of extraction procedure on yield, purity and antioxidant power of the extracts. Journal Food and Engineering, $78,793-80$. 
Tseng, A. \& Zhao, Y. (2013). Wine grape pomace as antioxidant dietary fiber for enhancing nutritional value and improving storability of yogurt and salad dressing. Food Chemistry 138(1), 356-365.

Zheng, Y., Lee Ch., Yu Ch., Cheng Yu, Simmons Ch., Zhang R., Jenkins B. \& Vander Gheynst J. (2012). Ensilage and bioconversion of grape pomace into fuel ethanol. Journal of Agricultural and Food Chemistry, 60(44), 11128-11134.

\section{Acnowledgment}

The present research was supported by the EU, FP7 - Regpot, the project No. 204756 and by the Ministry of Education and Science of the Republic of Serbia, the project No. 34012 and 31020.

Received for publication:

03.03.2014

Revision reveived:

08.05 .2014

Accepted for publication:

23.06.2014

\section{How to cite this article?}

Style - APA Sixth Edition:

Radovanović, V., Đekić, S., \& Radovanović, B. (2014, 07 15). Winery waste management in Serbia: Vranac grape marc as source of antioxidants. (Z. Čekerevac, Ed.) FBIM Transactions, 2(2), 2430. doi:10.12709/fbim.02.02.02.03

Style - Chicago Fifteenth Edition:

Radovanović, Vladimir, Snežana Đekić, and Blaga Radovanović. 2014. "Winery waste management in Serbia: Vranac grape marc as source of antioxidants." Edited by Zoran Čekerevac. FBIM Transactions (MESTE) 2 (2): 24-30. doi:10.12709/fbim.02.02.02.03.

Style - GOST Name Sort:

Radovanović Vladimir, Đekić Snežana and Radovanović Blaga Winery waste management in Serbia: Vranac grape marc as source of antioxidants [Journal] // FBIM Transactions / ed. Čekerevac Zoran. - Beograd : MESTE, 07 15, 2014. - 2 : Vol. 2. - pp. 24-30.

Style - Harvard Anglia:

Radovanović, V., Đekić, S. \& Radovanović, B., 2014. Winery waste management in Serbia: Vranac grape marc as source of antioxidants. FBIM Transactions, 15 07, 2(2), pp. 24-30.

Style - ISO 690 Numerical Reference:

Winery waste management in Serbia: Vranac grape marc as source of antioxidants. Radovanović, Vladimir, Đekić, Snežana and Radovanović, Blaga. 2014. [ed.] Zoran Čekerevac. 2, Beograd : MESTE, 07 15, 2014, FBIM Transactions, Vol. 2, pp. 24-30. 